\title{
THE NEEDS-NEXUS ANALYSIS: A UNIFIED TEST FOR VALIDATING SUBDIVISION EXACTIONS, USER IMPACT FEES AND LINKAGE
}

\author{
John J. Delaney,* \\ LARry A. Gordon, $\dagger$ \\ and Kathryn J. Hess**
}

\section{INTRODUCTION}

"I can resist everything except temptation," opined the pundit Oscar Wilde. ${ }^{1}$ Similarly afflicted, the authors of this article have followed in Wilde's way. Our temptation is the plethora of state court tests for assessing the validity of subdivision exactions and the emerging application, or potential application, of these disparate tests to the more recent phenomena of user impact fees and linkage. Our response to this siren's seduction is an attempt to unite these judicial standards, and to distinguish between traditional subdivision exactions, contemporary user impact fees, and linkage in applying our unified test. Thus, this article endeavors to create a unified universe of which it can be said, "and then there was one."

To ensure proper application of the judicial test set forth in this article, it is necessary to define and categorize the three governmental restrictions addressed herein. Accordingly, the definitions adopted by the authors and appropriate examples of each restriction are as follows:

1. Subdivision Exaction - Traditional construction, dedication, or in-lieu-fee payment for site-specific needs imposed at the time of subdivision. These improvements are usually categorized as being "minor" in scope and cost, and are typically provided onsite. Examples include subdivision streets, sidewalks, trails, utility easements, and open space.

2. User Impact Fee - More recent device to fund major, off-site infrastructure expansion imposed at the building permit stage. Examples include expansion or improvement of sewage treatment facilities, landfills, primary roadways, schools, and active recreational parks.

Copyright $\subset 1987$ by Law and Contemporary Problems

* Partner, Linowes and Blocher, Silver Spring, Greenbelt, and Annapolis, Maryland, and Washington, D.C.; Adjunct Professor, Land Use Law and Local Government Law, the American University, Washington College of Law.

$\dagger$ Associate, Linowes and Blocher, Silver Spring, Greenbelt, and Annapolis, Maryland, and Washington, D.C.

** Associate, Linowes and Blocher, Silver Spring, Greenbelt, and Annapolis, Maryland, and Washington, D.C.

1. O. Wilde, Lady Windermere's Fan 15 (lst collected ed. 1969). 
3. Linkage - Emerging technique of off-site development impact exaction, imposed at the certificate-of-occupancy stage upon large-scale mixed use or nonresidential developments, to promote social programs or policies. Examples include low- and moderate-income housing and job training.

It is a fundamental premise that, as municipalities grow, there is a continual need for new public improvements as well as for maintenance and expansion of existing infrastructure and public service facilities. Local jurisdictions have traditionally been responsible for the provision of major infrastructure improvements such as roads, schools, parks, sewage, and drainage facilities. Financing of these improvements has come from general revenues, most notably the real property tax, and through issuance of general obligation bonds which are repaid from local property tax revenues. Another primary source of infrastructure financing has been federal grant and subsidy programs, including the following:

-the Environmental Protection Agency Grant Program for the Construction of Waste Water Treatment Facilities; ${ }^{2}$

-the Economic Development Administration Public Works Program; ${ }^{3}$

-the Department of Housing and Urban Development Community and Urban

Development Grant Programs 4 and housing subsidy programs;

-Department of Transportation highway programs; and

-Urban Mass Transit Administration programs for public transit.

Because of the increasing unavailability of, or changing priorities for, federal, state, and local funds for public improvements, however, local jurisdictions have looked for new ways to finance these systems. Such phenomena as cutbacks in many of the aforementioned programs, limitations on local government's access to tax-free industrial revenue bonds as an economic development resource, and the uncertain specter of GrammRudman legislation ${ }^{5}$ have cast a pall upon the availability of federal funds in the foreseeable future. Similarly, state programs such as California's Proposition 13,6 and local enactments like the tax reform voter referendum (called "TRIM") in Prince George's County, Maryland,' have contributed to the problem.

One method for overcoming these fiscal constraints has been to rely on subdividers to construct or provide funds or land for improvements within the subdivisions they create, or to compel developers to contribute to the financing of off-site area-wide improvements at the time building permits are issued. Subdividers and developers, however, have not been reluctant to challenge these exaction measures in the courts. The challenges focus upon the authority of municipalities to impose these exactions and fees and the constitutionality of the devices themselves.

2. 40 C.F.R. $\$ \$ 35.800-.845$ (1986).

3. 13 C.F.R. $\$ \$ 305.1-.8(1986)$.

4. 24 C.F.R. $\$ \S 570.1-.913(1986)$.

5. Balanced Budget and Emergency Deficit Control (Gramm-Rudman) Act of 1985, 2 U.S.C. $\S \S 901-07,921-22$ (Supp. III 1986).

6. Cal. Const. art. XIIIA (1978).

7. Prince George's County, Md., Charter art. VIII, § 817B (1978). 
State courts have developed several tests for determining the constitutionality of exactions. These tests include the "reasonable relationship," "specifically and uniquely attributable," and "rational nexus" tests, as well as various combinations and permutations thereof. Although originally designed as tests for assessing the validity of subdivision exactions, these same tests have recently been applied to user impact fees and will likely be applied to the newest type of government imposed restriction, linkage. As noted, user impact fees and linkage regulations are now being used in new ways to help fund improvements necessitated by development in the region as a whole, rather than to address needs more directly attributable to a particular subdivision. As a result of this change in scope and purpose, the traditional judicial tests used to examine the constitutionality of subdivision exactions must be reevaluated. It is necessary to ascertain their continued validity in view of the expanded use of on-site exactions, as well as the advent of user impact fees and linkage.

\section{A. Historic Evolution}

The land dedication requirement, a form of subdivision exaction, was the first device used by local governments to shift improvement costs to subdividers and new residents. ${ }^{8}$ Early subdivision control ordinances required subdivision plats to be approved and recorded. ${ }^{9}$ Requirements that land be dedicated to the local government for streets, sidewalks, rights of way, utility easements, and drainage systems were often imposed as conditions on approval of these plats. ${ }^{10}$ The belief that the landowner's ability to subdivide his property was a privilege rather than a right justified this practice. ${ }^{11}$ The concept of dedications for on-site improvements, without compensation, has generally been upheld by the courts. ${ }^{12}$

From the dedication of land for on-site improvements, municipalities progressed to requiring the construction and dedication of on-site improvements. ${ }^{13}$ For example, at one time a town might have required a subdivider to dedicate land for public use, and the town itself would build the streets. Today, the municipality is more likely to require that the subdivider build the streets and then dedicate them to public use. ${ }^{14}$ This measure has also received general judicial approval. ${ }^{15}$

8. Pavelko, Subdivision Exactions: A Review of Judicial Standards, 25 WASH. U.J. URB. \& ConTemp. L. 269, 272 (1983).

9. See D. Mandelker, Land Use Law 262 (1982).

10. See Juergensmeyer \& Blake, Impact Fees: An Answer to Local Governments ' Capital Funding Dilemma, 9 Fla. ST. U.L. Rev. 415,418 (1981).

11. Pavelko, supra note 8 , at 283.

12. See id. at 273; Shultz \& Kelley, Subdivision Improvement Requirements and Guarantees: A Primer, 28

WASH. U.J. URB. \& Contemp, L. 3, 68 (1985).

13. Shultz \& Kelley, supra note 12 , at 68 .

14. D. MANDELKER, supra note 9 , at 267-68.

15. E.g., Ghen v. Piasecki, 172 N.J. Super. 35, 410 A.2d 708 (App. Div. 1980); see also Heyman \& Gilhool, The Constitutionality of Imposing Increased Community Cosis on New Suburban Residents through Subdivision Exactions, 73 YaLE L.J. 1119 , 1122 (1964). 
The next development in subdivision exactions required that developers provide land for on-site school and park purposes. Initially, these requirements did not receive the imprimatur of the courts. ${ }^{16}$ Although these dedications were for on-site improvements, the improvements would benefit members of the whole community, not just subdivision residents. As they have become more customary, however, courts have increasingly approved these requirements. ${ }^{17}$ This approval is premised on the rationale that residents of the new subdivisions will benefit from their proximity to the new facilities and open space. In addition, the developer may be able to charge higher sales prices and reap greater profits because of the amenities he has provided. ${ }^{18}$

Another form of subdivision exaction, the in-lieu fee, developed as a refinement of the dedication requirements. ${ }^{19}$ Many subdivisions were too small to be wholly responsible for the need for new schools, or to provide dedications appropriately sized for school sites, yet each subdivision contributed to the need for increased educational facilities. Municipalities therefore determined that the developer should pay in-lieu fees when land dedication was not practical. ${ }^{20}$ These fees are now also used to fund recreational and other types of facilities that are located off-site. ${ }^{21}$ In-lieu fees have not received unanimous approval from the courts. In some cases, they are classified as taxes and found to exceed the authority of the municipality. ${ }^{22}$ In other cases, however, they are upheld as valid exercises of the state's police power. ${ }^{23}$ Furthermore, some jurisdictions have even required off-site construction of lesser facilities in conjunction with subdivision approval. ${ }^{24}$ Like in-lieu fees, these off-site exactions for minor public improvements have also received ambivalent responses from the courts. ${ }^{25}$

\section{B. Recent Trends}

The most recent exaction devices imposed on developers by local governments are the user impact fee and linkage. The user impact fee is similar to the exaction in-lieu fee, but, as previously noted, its application is broader and more flexible. For example, user impact fees may be used to help fund area-wide projects such as large-scale sewage, water, and public

16. See Juergensmeyer \& Blake, supra note 10 , at 416 n.6.

17. See id. at 418 n.16.

18. See id.

19. Id. at 418 .

20. Pavelko, supra note 8, at 278.

21. Id.

22. E.g., City of Montgomery v. Crossroads Land Co., 355 So. $2 d 363$ (Ala. 1978); Town of Longboat Key v. Lands End, Lid., 433 So. 2d 574 (Fla. Dist. Ct. App. 1983); Sanchez v. City of Santa Fe, 82 N.M. 322, 481 P.2d 401 (1971); Haugen v. Gleason, 226 Or. 99, 359 P.2d 108 (1961).

23. See Pavelko, supra note 8, at 278-79.

24. D. MANDELKER, supra note 9 , at 268.

25. See, e.g., Ayres v. City Council, 34 Cal. 2d 31, 207 P.2d I (1949); see also Arnett v. City of Mobile, 449 So. 2d 1222, 1224 (Ala. 1984) (city required to compensate developer for reservation of land outside subdivision for future street when lots not sold "pursuant to the plat of the future thoroughfare"). 
safety facilities. ${ }^{26}$ In addition, although exaction dedications and in-lieu fees are required when subdivision plans are submitted, user impact fees are collected later in time, usually when building permits are issued. As a result, the funds generated by user impact fees become available for governmental use at a period closer to the time when the additional services will be demanded.27 Yet another difference between the measures is the method used to calculate the appropriate amount required. In-lieu fees are usually set at the value of a percentage of acreage. The calculation of user impact fees is generally based on the square footage of proposed buildings, or the number of bedrooms or living units in a development. Thus, user impact fees can be applied to condominium, apartment, and commercial developments, uses to which exaction in-lieu fees are typically inapplicable. ${ }^{28}$

Courts have treated user impact fees in a fashion similar to that commonly accorded in-lieu exaction fees. Impact fees are either held unconstitutional as unauthorized taxes, ${ }^{29}$ or are supported on police power rationales. ${ }^{30}$ Generally, however, challenges to the validity of user impact fees do not succeed under the current judicial tests applied in subdivision exaction cases.

Linkage is a new concept that courts have not yet addressed in depth. ${ }^{31}$ Now used in Boston and San Francisco, and proposed in Chicago and other cities, this technique seeks to obtain private sector assistance for the provision of low- and moderate-income housing, and has been suggested for other social programs such as job training. ${ }^{32}$ These linkage programs link the right to construct new large-scale mixed use or nonresidential developments to the

26. Juergensmeyer \& Blake, supra note 10, at 419-20.

27. D. MANDELKER, supra note 9 , at 272.

28. Juergensmeyer \& Blake, supra note 10 , at 419 . For a description of the many advantages of impact fees, see $i d$. at 420.

29. E.g., Broward County v. Janis Dev., 311 So. 2d 371 (Fla. Dist. Ct. App. 1975); VendittiSiravo, Inc. v. City of Hollywood, 39 Fla. Supp. 121 (Cir. Ct. 1973); West Park Ave., Inc. v. Ocean Township, 48 N.J. 122, 224 A.2d I (1966); Lafferty v. Payson City, 642 P.2d 376 (Utah 1982); Hillis Homes, Inc. v. Snohomish County, 97 Wash. 2d 804, 650 P.2d 193 (1982) (superseded by WASH. Rev. Code ANn. \$ 82.02.020 (Supp. 1987)).

30. E.g., Contractors \& Builders Ass'n v. City of Dunedin, 329 So. 2d 314 (Fla. 1976) (impact fee valid under police power but struck because of insufficient restrictions on use of funds collected), reconsidered on appeal from unpublished remand, 358 So. 2d 846 (Fla. Dist. Ct. App. 1978) (amended exaction held legal), cert. denied, 370 So. 2d 458, cert. denied, 444 U.S. 867 (1979); Hollywood, Inc. v. Broward County, 431 So. 2d 606 (Fla. Dist. Ct. App. 1983); Coulter v. City of Rawlins, 662 P.2d 888 (Wyo. 1983). See generally Connelly, Road Impact Fees Upheld in Noncharter County, 58 FLA. B.J. 54 (1984).

31. See Smith, From Subdivision Improvement Requirements to Community Beneft Assessments and Linkage Payments: A Brief History of Land Development Exactions, Law \& Contemp. ProbS., Winter 1987, at 5. In April 1986, a lower court in Massachusetts struck down the city of Boston's linkage program, holding that the City Council lacked the legal authority to approve it, and that the fee was a tax not authorized by the state constitution. Bonan v. General Hosp. Corp., No. 76438 (Mass. Super. Ct. Mar. 31, 1986) (order granting summary judgment). The Massachusetts Supreme Court later reversed the lower court decision on procedural grounds. See Bonan v. City of Boston, 398 Mass. 314, 496 N.E.2d 640 (1986).

32. See Boston, Mass., Zoning Code art. 26 (1983), amended by Boston, Mass., Zoninc, Code art. 26A (1986); San Francisco, Cal., Ordinance 358-85 (Aug. 18, 1985). For a discussion of the San Francisco ordinance, see Share \& Diamond, San Francisco Office-Housing Production Program, Land Use. L. \& Zoning Dig., Oct. 1983, at 4, 4-6; see also Smith, supra note 31, at 25-28. 
provision of new housing. ${ }^{33}$ For example, San Francisco has developed a formula, based on the number of workers expected to occupy the proposed office space, to calculate the amount of housing a developer is required to help provide. ${ }^{34}$ Thus, the requirement is directly tied to needs purportedly generated by the new office development.

Linkage is an extension of the impact fee concept. ${ }^{35}$ Through linkage, municipalities are attempting to finance new housing and social programs in the same way that they finance new public facilities. ${ }^{36}$ The constitutional validity test discussed in Section IV of this article can therefore be applied to linkage programs, as well as to user impact fees and subdivision exactions.

As noted, local governments have heretofore relied primarily on long-term debt financing, federal grants, and real estate taxes to finance new public facilities. ${ }^{37}$ However, as public funding has been cut back, ${ }^{38}$ and the need for more advanced facilities has arisen, ${ }^{39}$ municipalities have been forced to find other means of funding those facilities. Recent national economic recessions, combined with attempts to balance the federal budget without increasing taxes, have contributed to the decrease in federal funding of state and local infrastructure improvement projects. ${ }^{40}$ Simultaneously, taxpayer pressure on all levels of government to reduce expenditures has resulted in corresponding state and local funding cutbacks. ${ }^{41}$ Furthermore, since the federal share of capital investment actually increased during the 1970 's, ${ }^{42}$ the current reduced availability of federal funds has particularly aggravated the fiscal problems of local governments. In addition to the need for new facilities, there also is currently a great need for maintenance expenditures along with large capital debts to repay.

Increasingly, local governments are experimenting with new devices, such as user impact fees and linkage, in an attempt to impose larger public improvement burdens on the private sector. ${ }^{43}$ Simultaneously, there is

33. Smith, supra note 31 , at 25 .

34. San Francisco, Cal., Ordinance 358-85 (Aug. 18, 1985); Smith supra note 31, at 25-27; see Connors, Development Exactions: Attack and Defense 473, 477 (July 22, 1985) (unpublished paper presented at the ALI-ABA Land Use Institute, Aug. 13-16, 1985, Boulder, Colo.).

35. Smith, supra note 31 , at 25; Connors, supra note 34 , at 475 .

36. Keating, Linking Downtown Development to Broader Community Goals, 2 J. AM. PLAN. A. 133 (1986).

37. Builder and Ass'n Services Div., National Ass'n of Home Builders, Impact Fees: A Developer's Manual 3, 4 [hereinafter NAHB Developer's Manual]; 2 P. Rohan, Zoning and Land Use Controls \$ 9.01[1] (1986); Urban Land Inst., Financing Local Infrastructure in a Time of Fiscal Constraint, URB. LAND, Aug. 1983, at 16, 17-18. [hereinafter ULI Statement].

38. According to the Urban Land Institute, infrastructure investment decreased by $44 \%$ from 1968 to 1983 . ULI Statement, supra note 37 , at 16.

39. There have been increased requirements geared to health and environmental protection. At the same time, population and economic growth have continued to increase as the baby boom generation grows older. $I d$. at 18.

40. ULI Statement, supra note 37 , at 16 .

41. Id.; NAHB Developer's Manual, supra note 37, at 3.

42. ULI Statement, supra note 37 , at 17.

43. NAHB Developer's Manual, supra note 37, at 3; Ul.I Statement, supra note 37 , at $16,18$. There are several problems with this increased reliance on the private sector. First, in the long run, the cost of financing infrastructure improvements will be greater because short-term capital is costly 
growing confusion in the courts about how to evaluate the constitutional validity of these new measures. Several divergent tests for evaluating the validity of subdivision exactions have developed in the state courts. The standards imposed by these state court tests range from judicial deference toward the legislative enactments to the stringent requirement that the need for an exaction be specifically and uniquely attributable to a proposed subdivision. Furthermore, these state tests fail to draw a discernible distinction between traditional subdivision exactions and user impact fees. Yet the different degree of burden imposed by the regulations should compel the reviewing courts to distinguish between them. User impact fees involve large-scale, off-site regional public facilities, the need for which is not directly attributable to a particular subdivision. Moreover, the cost of such facilities may become prohibitive to the consumer and ultimately exclusionary for certain economic classes.

In addition, there is no federal test for evaluating the validity of subdivision exactions or user impact fees. Although some decisions have been appealed to the United States Supreme Court, they have been dismissed for want of a substantial federal question. ${ }^{44}$ Thus to avoid further confusion, state and federal courts alike should adopt a single, flexible test for evaluating the constitutional validity of subdivision exactions, user impact fees, and linkage.

This unified test should consider and balance the divergent equities and interests of government, developers and consumers, the last of whom will ultimately pay for these public improvements. If properly designed and implemented, such a test, as applied to exactions, fees, and linkage, would resolve the challenge posed by Edwin Markham in "Man-Making":

Why build these cities glorious,

If man unbuilded goes?

In vain we build the world,

Unless the builder also grows? ${ }^{45}$

The task at hand is thus to promote the health, safety, and welfare of the community while recognizing the legitimate interests of developers and consumers.

and difficult for developers to secure. Second, the additional time required to obtain the funds to pay the impact fees will lead to increases in developers' costs and housing prices. Third, the additional cost, delays, and uncertainty will act as a disincentive for economic development. Fourth, in many cases, service standards will be lowered. Finally, municipal control over the design, timing, and quality of facility development will decrease. NAHB Developer's MANUAL, supra note 37 at 5; ULI Statement, supra note 37, at 18-19.

44. Associated Home Builders v. City of Walnut Creek, 4 Cal. 3d 633, 484 P.2d 606, 94 Cal. Rptr. 630 (1971), appeal dismissed, 404 U.S. 878 (1972); Home Builders \& Contractors Ass'n v. Board of County Comm'rs, 446 So. 2d 140 (Fla. Dist. Ct. App. 1983), appeal dismissed, 469 U.S. 976 (1984); Jordan v. Village of Menomonee Falls, 28 Wis. 2d 608, 137 N.W.2d 442 (1965), appeal dismissed, 385 U.S. 4 (1966). However, a case is presently pending before the United States Supreme Court in which a subdivision exaction is at issue. Nollan v. California Coastal Comm., 177 Cal. App. 3d 719 , 223 Cal. Rptr. 28, prob. juris. noted, 107 S. Ct. 312 (1986).

45. E. Markham, Man-Making, in The Gates of Paradise and Other Poems 20 (1920). 
Traditional Judicial Tests

\section{A. Statutory Authorization}

Typically, challenges to exaction dedication and fee requirements, as well as to user impact fees, initially assert that the local government does not have the authority to impose such a requirement. Because all local power is derived from the state, the court will look to the applicable state enabling legislation to determine whether the state has authorized the locality to require exactions or impact fees from subdividers or developers, respectively. The court must also look at local ordinances to determine what types of subdivision exactions or user fees are authorized. ${ }^{46}$ In some instances, even if there is no express authorization, courts will find implied authority. ${ }^{47}$ In jurisdictions that adhere to Dillon's Rule, ${ }^{48}$ however, the powers of local governments will be construed narrowly, and an exaction or fee not expressly authorized or necessarily implied from such express authorization will not survive judicial scrutiny. ${ }^{49}$

Generally, courts have upheld requirements that subdividers provide internal street and public facility improvements. ${ }^{50}$ Requirements of this type are expressly authorized in the Standard City Planning Enabling Act ${ }^{51}$ and in most state statutes. ${ }^{52}$ However, exactions for parks, schools, minor off-site improvements, and in-lieu fees, as well as off-site user impact fees, are rarely expressly authorized by state legislation. ${ }^{53}$ Some state courts, including those in New Jersey and Utah, have found implied authority for some types of off-

46. See, e.g., Kamhi v. Planning Bd., 59 N.Y.2d 385, 452 N.E.2d 1193, 465 N.Y.S.2d 865 (1983); Riegert Apartments Corp. v. Planning Bd., 57 N.Y.2d 206, 441 N.E.2d 1076, 455 N.Y.S.2d 558 (1982); see also P. Rohan, supra note 37, at $\$$ 9.04[2] (1986); Johnston, Constitutionality of Subdivision Control Exactions: The Quest for a Rationale, 52 Cornell L.Q. 871, 887-88 (1967).

47. See, e.g., Savonich v. Township of Lawrence, 91 N.J. Super. 288, 219 A.2d 902 (Law Div. 1966).

48. Dillon maintains that:

It is a general and undisputed proposition of law that a municipal corporation possesses and can exercise the following powers, and no others: First, those granted in express words; second, those necessarily or fairly implied in or incident to the powers expressly granted; third, those essential to the accomplishment of the declared objects and purposes of the corporation-not simply convenient, but indispensible.

$1 \mathrm{~J}$. Dillon, Commentaries on the law of Municipal Corporations $\$ 237$ (5th ed. 1911 ).

49. See, e.g., Hylton Enters. v. Board of Supervisors, 220 Va. 435, 258 S.E.2d 577 (1979).

Several other courts have held that clear statutory authority is required. E.g.. Krughoff v. City of Naperville, 4 I Ill. App. 3d 334, 354 N.E.2d 489 (1976), affd, 68 Ill. 2d 352, 369 N.E.2d 892 (1977); Middlesex \& Boston St. Ry. v. Board of Aldermen, 371 Mass. 849, 359 N.E.2d 1279 (1977); Arrowhead Dev. Co. v. Livingston County Rd. Comm'n, 413 Mich. 505, 322 N.W.2d 702 (1982); Home Builders Ass'n v. City of Kansas City, 555 S.W.2d 832 (Mo. 1977); West Park Ave., Inc. v. Ocean Township, 48 N.J. 122, 224 A.2d 1 (1966); Kamhi v. Planning Bd., 59 N.Y.2d 385, 452 N.E.2d 1193, 465 N.Y.S.2d 865 (1983); Reigert Apartments Corp. v. Planning Bd., 57 N.Y.2d 206, 441 N.E.2d 1076, 455 N.Y.S.2d 558 (1982).

50. See Heyman \& Gilhool, supra note 15, at 1122 .

51. Standard City Planning Enabling Act tit. II, $\S 14$ (1928).

52. See D. MANDElkER, supra note 9, at 262, 267.

53. Id. at 268. 
site exactions. ${ }^{54}$ Other courts, such as those in Virginia and Nebraska, have held that there is no implied authority to require off-site improvements. ${ }^{55}$

\section{B. Constitutionality Tests}

Once a court has determined that the municipality has the authority to impose the exaction or fee, it will assess the constitutionality of the regulation. This inquiry focuses on the relationship between the regulation and the needs generated by the proposed development. Requirements for improvements within a subdivision will usually survive constitutional scrutiny under a needbenefit test. For example, in Blevens $v$. City of Manchester, ${ }^{56}$ the New Hampshire Supreme Court found that it is reasonable to impose on the subdivider the cost of "improvements which are of special benefit to the subdivision," since the subdivider, rather than the municipality, creates the need for the improvements. ${ }^{57}$

When the improvements serve members of the general public as well as residents of the subdivision, it is more difficult to assess their constitutionality. Subdividers and developers frequently assert that these regulations constitute takings of property without compensation in violation of the U.S. Constitution or state constitutions. ${ }^{58}$ To answer this charge, courts must consider the particular regulation in its context. They must determine whether the regulation is a valid exercise of the state's police power ${ }^{59}$ or whether it is an unconstitutional taking in contravention of the fifth and fourteenth amendments. ${ }^{60}$

The original rationale underlying subdivision control was a theory of voluntariness. Developers were viewed as voluntarily choosing to subdivide their land and subject themselves to the conditions imposed by local

54. E.g., Divan Builders, Inc. v. Planning Bd., 66 N.J. 582, 334 A.2d 30 (1975) (drainage facility improvement); Call v. City of W. Jordan, 606 P.2d 217 (Utah 1979) (flood control, parks, or recreation facilities).

55. E.g., Briar West, Inc. v. City of Lincoln, 206 Neb. 172, 291 N.W.2d 730 (1980); Hylton Enters. v. Board of Supervisors, 220 Va. 435, 258 S.E.2d 577 (1979).

56. 103 N.H. 284, 170 A.2d 121 (1961).

57. Id. at $286,170 \mathrm{~A} .2 \mathrm{~d}$ at $122-23$.

58. See Heyman \& Gilhool, supra note 15, at 1126-30; see also Krambeck v. City of Gretna, 198 Neb. 608, 254 N.W.2d 691 (1977); Van Dissel v. Jersey Cent. Power \& Light, 152 N.J. Super. 391 , 377 A.2d 1244 (Law Div. 1977).

59. Local governments, as subdivisions of the state, may exercise the state's police powers. Thus, they are empowered to protect the public health, safety, morals, or general welfare. See Pavelko, supra note 8, at 280 n.60; see also R. Rotunda, J. Nowak \& J. Young, Treatise on Constitutional Law: Substance and Procedure $\$ \$ 15.1,15.10$ (1986) [hereinafter R. Rotunda].

60. The fifth and fourteenth amendments to the U.S. Constitution prohibit the taking of private property for public use without just compensation. U.S. ConST. amend. V, XIV. For a general discussion of takings, see R. Rotunda, supra note 59 , at $\$ 15.12$; see also F. Bosselman, D. Callies \& J. Banta, The Taking Issue (1973). The law concerning the taking issue is now very confused. See $R$. RoTUNDA, supra note 59, at $\$ \S 15.12$ (b), (d), 15.14; Williams, Smith, Siemon, Mandelker \& Babcock, The White River Junction Manifesto, 9 VT. L. REv. 193, 225-33 (1984); Berger \& Kanner, Thoughts on The White River Junction Manifesto: A Reply to the "Gang of Five's" Views on Just Compensation for Regulatory Taking of Property, 19 Loy. L.A. L. REv. 685 (1986); see also Bauman, The Supreme Court, Inverse Condemnation and the Fifth Amendment: Justice Brennan Confronts the Inevitable in Land Use Controls, 15 RutGers L.J. 15 (1983). 
government. ${ }^{61}$ However, as the goals these controls were intended to promote have changed, the underlying rationale has progressed "from 'voluntariness,' to 'privilege,' to the 'police power'."62

Although the right-privilege distinction has generally been abandoned in constitutional law, some courts still employ it when deciding exaction and impact fee cases. ${ }^{63}$ These courts hold that the subdivision of land is a privilege granted to the subdivider or developer by the municipality and is subject to any requirements the municipality may impose. ${ }^{64}$ More often, however, courts employ one of the following three tests: reasonable relationship, specifically and uniquely attributable, or rational nexus. In applying these tests, courts consider the relationship between the regulation, the benefits derived from the improvements, and the need for the improvements created by the subdivision.

1. The Reasonable Relationship Test. In 1949, in Ayres v. City Council, 65 the California Supreme Court formulated a flexible test to determine the constitutionality of subdivision exaction land dedication requirements. Its reasonable relationship test considers whether the proposed development will contribute to the problem sought to be alleviated by imposition of the regulation. ${ }^{66}$ This test has since been characterized as one that, when applied, tends to result in approval of the requirements. ${ }^{67}$ Application of this test, however, does not result in approval in all cases. ${ }^{68}$

The Ayres court considered the needs created by the subdivision and the benefits of the required dedication. It held that "where [the dedication of land for streets] is a condition reasonably related to increased traffic and other needs of the proposed subdivision it is voluntary in theory and not contrary to constitutional concepts." 69 Relying in part on the voluntariness and privilege theories, the court found that the subdivider sought the advantages of lot subdivision. Therefore, he had to comply with reasonable conditions imposed to protect the "safety and general welfare of the lot owners in the subdivision and of the public."70 Thus, the exaction dedication requirement was a reasonable exercise of the police power, not a compensable taking.

A lower California court recently applied this test to an ordinance that required the payment of user impact fees. In Building Industry Association of Southern California v. City of Oxnard, ${ }^{71}$ the court held that the impact fees were

61. Pavelko, supra note 8 , at 283.

62. Johnston, supra note 46 , at 876 .

63. D. MANDELKER, supra note 9 , at 268.

64. See Pavelko, supra note 8 , at 283.

65. 34 Cal. 2d 31, 207 P.2d 1 (1949).

66. Id.

67. Wald Corp. v. Metropolitan Dade County, 338 So. 2d 863, 866 (Fla. Dist. Ct. App. 1976), cert. denied, 348 So. 2d 955 (1977).

68. See, e.g., Howard County v. JJM, Inc., 301 Md. 256, 482 A.2d 908 (1984).

69. 34 Cal. 2d at 42, 207 P.2d at 8.

70. Id. at $42,207 \mathrm{P} .2 \mathrm{~d}$ at 7.

71. 150 Cal. App. 3d 535 (text of opinion not printed), 198 Cal. Rptr. 63 (1984), vacated, 40 Cal. 3d 1, 706 P.2d 285, 218 Cal. Rptr. 672 (1985). 
not a valid police power measure but a mask for discriminatory taxation. To determine whether the fees actually were a valid police power device, the court applied the reasonable relationship test as stated in Liberty $v$. California Coastal Commission: ${ }^{72}$

Whether there has been a reasonable exercise of the police power is a question for the court. Where the conditions imposed are not related to the use being made of the property but are imposed because the [governmental] entity conceives a means of shifting the burden of providing the cost of a public benefit to another not responsible for or only remotely or speculatively benefiting from it, there is an unreasonable exercise of the police power. ${ }^{73}$

The Oxnard court found no reasonable relationship between the impact fees and the need for public improvements generated by the assessed developments. Instead, the fees were "designed to collect revenue for 'general purpose capital needs' benefiting the community as a whole." 74

The test enunciated in Ayres has also been employed by other state courts. In Call v. City of West Jordan, ${ }^{75}$ the Utah Supreme Court determined that this test should be applied to an ordinance requiring the dedication of land or an in-lieu fee for flood control or park and recreational facilities. It held that the plaintiff subdividers should have an opportunity to present evidence on this issue and remanded the case to the lower court to afford them that opportunity. ${ }^{76}$

The Maryland Court of Appeals also recently applied the reasonable relationship test. Howard County $v . J J M$, Inc ${ }^{77}$ addressed a county statute that required the developer to reserve, rather than dedicate, a right of way within the subdivision for a proposed state road. The land was to be reserved for an "indefinite period of time."78 Following the line of reasoning employed in Ayres, the court asked "whether the proposed subdivision reasonably generates the need for the highway in question." 79 Finding that the exaction deprived the developer of any use of his land and that the county had not shown a reasonable nexus between the exaction and the proposed subdivision, the court held the statute unconstitutional as applied. ${ }^{80}$

2. The Specifically and Uniquely Attributable Test. The Illinois courts have adopted a test diametrically opposed to the reasonable relationship test. In 1961, the Illinois Supreme Court, in Pioneer Trust and Savings Bank v. Village of Mount Prospect, ${ }^{81}$ set forth a very stringent test. The court specified that the need for the subdivision exaction must be specifically and uniquely

72. 113 Cal. App. 3d 491, 502-03, 170 Cal. Rptr. 247, 254 (1980).

73. 150 Cal. App. at,- 198 Cal. Rptr. at 65 (citation omitted).

74. Id. at -, 198 Cal. Rptr. at 66.

75. 614 P.2d 1257 (Utah 1980).

76. Id. at 1259 .

77. 301 Md. 256, 482 A.2d 908 (1984).

78. Id. at $260,482 \mathrm{~A} .2 \mathrm{~d}$ at 910 .

79. Id. at $258,482 \mathrm{~A} .2 \mathrm{~d}$ at 909 .

80. Id. at $282,482 \mathrm{~A} .2 \mathrm{~d}$ at 921 .

81. 22 Ill. 2 d 375,176 N.E.2d 799 (1961). 
attributable to the subdivider's activity in order to be found permissible. ${ }^{82}$ Absent this relationship, the exaction would be "a confiscation of private property in contravention of the constitutional prohibitions rather than [a] reasonable regulation under the police power." 83 Applying this strict standard, the court held that the required dedication of land for school and recreational facilities, although desirable, was impermissible. The court explained:

[T]his record does not establish that the need for recreational and educational
facilities... is one that is specifically and uniquely attributable to the addition of the
subdivision and which should be cast upon the subdivider as his sole financial burden
$\ldots .$. [T] pe present school facilities of Mount Prospect are near capacity. This is the
result of the total development of the community. If this whole community had not
developed to such an extent or if the existing school facilities were greater, the
purported need supposedly would not be present. Therefore, on the record in this
case the school problem which allegedly exists here is one which the subdivider should
not be obliged to pay the total cost of remedying, and to so construe the statute would
amount to an exercise of the power of eminent domain without compensation. 84

Thus, although the court found that the addition of the houses in the new subdivision would aggravate the problem, it was unwilling to make the developer pay for part of the remedy.

The specifically and uniquely attributable test has been generally accepted by the Illinois courts as the standard for determining the reasonableness of subdivision exactions. ${ }^{85}$ In Rosen v. Village of Downers Grove, ${ }^{86}$ the court applied the test and struck down an in-lieu fee requirement. In a later application of the test to an internal street exaction, the court also held the requirement unconstitutional. ${ }^{87}$ In Board of Education v. Surety Developers, ${ }^{88}$ however, the court found that the test had been satisfied. It held that the conditions imposed on the subdivider were reasonable in light of the subdivision's contribution to the creation of the school problem. The court also found that the test had been met in Krughoff $v$. City of Naperville, ${ }^{89}$ where in-lieu fees for parks and schools were "fairly proportioned to the need for new ... facilities created by the proposed developments." 90

Courts in several other states have also applied the specifically and uniquely attributable test. In Frank Ansuini, Inc. v. City of Cranston, ${ }^{91}$ the Rhode Island Supreme Court held that park and recreational land dedication requirements are acceptable, but only when the strict Pioneer Trust test has been met. It also held that an ordinance with a set percentage requirement was arbitrary and unreasonable, but that a land dedication requirement that

\footnotetext{
82. Id. at 380,176 N.E.2d at 802 .

83. Id.

84. Id. at $381-82,176$ N.E.2d at 802 .

85. See Pavelko, supra note 8 , at 285.

86. 19 Ill. 2d 448, 167 N.E.2d 230 (1960).

87. Exchange Nat'l Bank v. City of Lake Forest, 40 Ill. 2d 281, 239 N.E.2d 819 (1968).

88. 63 Ill. 2d 193, 347 N.E.2d 149 (1975).

89. 68 Ill. 2d 352, 369 N.E.2d 892 (1977).

90. Id. at 359,369 N.E.2d at 895 .

91. 107 R.I. 63,264 A.2d 910 (1970).
} 
was specifically and uniquely attributable to the new subdivision would be appropriate and more equitable. ${ }^{92}$

Courts in Oregon and Connecticut have applied the specifically and uniquely attributable test to in-lieu payment requirements. In Haugen $v$. Gleason, ${ }^{93}$ the Oregon Supreme Court characterized the in-lieu fee requirement as a tax and held that the city did not have the authority to impose it on subdividers. In addition, the court held that even if the city had the authority to impose the fee requirement, it was unconstitutional unless the money collected was earmarked for expenditures that would benefit the regulated subdivision. Similarly, a Connecticut court invalidated a regulation authorizing in-lieu payments because no provision specifically required that the money collected be spent in a manner directly beneficial to the regulated subdivision. ${ }^{94}$

More recently, the New Hampshire Supreme Court applied the test to a local exaction ordinance that required the dedication of seven and a half percent of the total acreage of a subdivision or the payment of an in-lieu fee. ${ }^{95}$ Because evidence was produced that indicated that the town did not need or intend to use the dedicated land, the court held that the requirement was arbitrary and unconstitutional. 96

Thus, the specifically and uniquely attributable test requires that there be a "spatial proximity between the improvement and the [developer's] property, a correlation between the cost and the provable benefit, and an improvement capable of being exactly financed or proportioned." 97 Several courts have rejected this test because of these strict standards. One court actually acknowledged the test as "an acceptable statement of the yardstick to be applied,"98 but did not apply it because of the proof problems its restrictive application would cause:

In most instances it would be impossible for the municipality to prove that the land required to be dedicated for a park or a school site was to meet a need solely attributable to the anticipated influx of people into the community to occupy this particular subdivision. ${ }^{99}$

Other courts have preferred to apply more flexible standards that permit municipalities to require contributions from small developments that generate needs but that cannot dedicate large pieces of land, or from those that generate needs for new or improved services in conjunction with other new developments.

92. Id. at 70-71, 264 A.2d at 913-14.

93. 226 Or. 99, 359 P.2d 108 (1961).

94. Aunt Hack Ridge Estates, Inc. v. Planning Comm'n, 27 Conn. 74, 230 A.2d 45 (1967).

95. J.E.D. Assocs. v. Town of Atkinson, 121 N.H. 581, 432 A.2d 12 (1981).

96. Id. at $584,432 \mathrm{~A} .2 \mathrm{~d}$ at 14 .

97. Holmes v. Planning Bd., 78 A.D.2d 1, 17, 433 N.Y.S.2d 587, 598 (1980).

98. Jordan v. Village of Menomonee Falls, 28 Wis. 2d 608, 617, 137 N.W.2d 442, 447 (1965), appeal dismissed, 385 U.S. 4 (1966).

99. Id. at 617,137 N.W.2d at 447. 
3. The Rational Nexus Test. In Jordan v. Village of Menomonee Falls, ${ }^{100}$ the Wisconsin Supreme Court set forth a new and more moderate standard for assessing exaction validity. ${ }^{101}$ The court's rational nexus test required a reasonable connection between the exaction and the needs created by or the benefits conferred upon the new subdivision. ${ }^{102}$ Under this test, the court would not declare a regulation unconstitutional simply because the proposed subdivision had not solely created the need. Instead, it would find a reasonable basis for the imposition of the regulation if "a group of subdivisions approved over a period of several years had been responsible for bringing into the community a considerable number of people" which necessitated the provision of additional educational and recreational facilities. ${ }^{103}$ A subdivider could overcome the presumption of the exaction's validity, however, by providing evidence demonstrating that

(i) the municipality already has adequate land for parks to meet its present and future needs;

(ii) normal growth, irrespective of the growth due to the subdivision, would make the land acquisition necessary; or,

(iii) the subdivision will merely cause an intramunicipality population shift and not result in a substantial influx of people. ${ }^{104}$

If such evidence was not provided, the collection of in-lieu fees to finance the improvements would be allowed.

The Jordan court also impliedly required a reasonable connection between the expenditure of the funds collected and the benefits accruing to the assessed subdivision. ${ }^{105}$ The court would not hold the exaction to be unreasonable simply because some of the benefits resulting from the improved facilities would accrue to the general public. Nevertheless, the reasonableness of the exaction would depend on a factual inquiry into the relationship between the expenditure of the funds and the benefits accruing to the subdivision. ${ }^{106}$

Although Jordan involved the payment of in-lieu fees, the court considered the constitutionality of subdivision exactions generally. It first determined that an exaction dedication requirement would be deemed constitutional if it met the rational nexus test. ${ }^{107}$ It then considered the constitutionality of an

100. 28 Wis. 2d 608, 137 N.W.2d 442 (1965).

101. A Florida court described the rational nexus approach articulated by the Wisconsin Supreme Court in Jordan as providing "a more feasible basis for testing subdivision dedication requirements" than the specifically and uniquely attributable test or the reasonable relationship standard. Wald Corp. v. Metropolitan Dade County, 338 So. 2d 863, 868 (Fla. Dist. Ct. App. 1976), cert. denied, 348 So. $2 \mathrm{~d} 955$ (1977).

102. 28 Wis. 2 d at $618-19,137$ N.W.2d at 448; see also Juergensmeyer \& Blake, supra note 10 , at 430-33.

103. 28 Wis. $2 \mathrm{~d}$ at $617-18,137$ N.W.2d at 447.

104. Id. at 618, 137 N.W.2d at 448; see also Gordon, Subdivision Exactions Draw Challenges from Developers, Legal Times of Wash., Sept. 2, 1985, at A4, col. 3, A14, col. 3.

105. 28 Wis. 2d at 617-18, 137 N.W.2d at 447; see also Juergensmeyer \& Blake, supra note 10, at 432.

106. See Juergensmeyer \& Blake, supra note 10 , at 432.

107. The court did not actually use the term "rational nexus" to describe its test. See Juergensmeyer \& Blake, supra note 10, at 431 n.93. 
equalization fee charged in lieu of the dedication. Although the municipality was not specifically authorized to charge the fee, the court found that its purpose was closely tied to the purpose of the authorized dedication requirement. Therefore, the equalization fee was also legal and a constitutional exercise of the police power, where the subdivided tract of land was so small that a dedication requirement would have been impractical. ${ }^{108}$

Courts in several other states have applied the test developed in Jordan. For example, the court in Associated Home Builders v. City of Walnut Creek, ${ }^{109}$ applied the rational nexus test although the plaintiff argued that it should have applied the stricter specifically and uniquely attributable test. Holding that the city ordinance would "be justified on the basis of a general public need for recreational facilities caused by present and future subdivisions," 110 the California Supreme Court explained:

We see no persuasive reason in the face of these urgent needs caused by present and
anticipated future population growth on the one hand and the disappearance of open
land on the other to hold that a statute requiring the dedication of land by a
subdivider may be justified only upon the ground that the particular subdivider upon
whom an exaction has been imposed will, solely by the development of his
subdivision, increase the need for recreational facilities to such an extent that
additional land for such facilities will be required.111

Because the need for the facilities was generated in part by the plaintiff's subdivision, the court upheld the ordinance authorizing land dedications or in-lieu fees.

The New Hampshire Supreme Court, in Land/Vest Properties, Inc. v. Town of Plainfield, ${ }^{112}$ considered the constitutionality of a requirement that a subdivider upgrade two off-site access roads. Because two residences and three undeveloped lots bordered on the roads and the required improvements were to extend well beyond the proposed subdivision, the court determined that it would be inequitable to impose the entire cost of improving the roads on the subdivider. ${ }^{13}$ Instead, the court held that a subdivider should be required to bear only "that portion of the cost [of the off-site improvements] that bears a rational nexus to the needs created by, and special benefits conferred upon, the subdivision."114 The determination of the subdivider's appropriate portion of the cost would involve a factual inquiry into such matters as the road maintenance standard currently applied, the frontage of the subdivision, the potential traffic increase, and the number of homes currently fronting on the roads. ${ }^{115}$

108. 28 Wis. $2 d$ at $608,618-23,137$ N.W.2d at $448-50$.

109. 4 Cal. 3d 633, 484 P.2d 606, 94 Cal. Rptr. 630 (1971), appeal dismissed, 404 U.S. 878 (1972).

110. Id. at 638, 484 P.2d at 611,94 Cal. Rptr. at 634.

111. Id. at 639-40, 484 P.2d at 611,94 Cal. Rptr. at 635.

112. 117 N.H. 817,379 A.2d 200 (1977).

113. Id. at $822,379 \mathrm{~A} .2 \mathrm{~d}$ at 204 .

114. Id. at 823, 379 A.2d at 204 (citing Longridge Builders, Inc. v. Planning Bd., 52 N.J. 348, 350 , 245 A.2d 336,337 (1960)).

115. Id. at 824,379 A.2d at 205. 
In Wald Corp. v. Metropolitan Dade County, ${ }^{116}$ a Florida court rejected both the reasonable relationship test and the specifically and uniquely attributable test. While the former test would allow local governments too much discretion in the imposition of subdivision exactions and too much opportunity to interfere with private property, the latter test was deemed excessively restrictive. The Florida court preferred the more moderate rational nexus test. Explaining its choice, the court described the standard as one that
allows the local authorities to implement future oriented comprehensive planning without according undue deference to legislative judgments. It requires a balancing of the prospective needs of the community and the property rights of the developer. But above all, it treats the business of subdividing as a profitmaking enterprise, thus drawing proper distinctions between the individual property holder and the subdivider. While the former may not ordinarily have his property appropriated without an eminent domain proceeding, the latter may be required to dedicate land where the requirement is part of a valid regulatory scheme. ${ }^{117}$

The court applied the test to the dedication requirements at issue. A subdivider had challenged the constitutionality of a county ordinance that required the dedication of land for canal rights of way and maintenance easements. ${ }^{118}$ Part of the justification for the requirement was that the county's adopted water control plan included the canal system. As a result, the court found that the drainage provisions would benefit the subdivision itself, as well as land located both upstream and downstream, by protecting them from periodic flooding. ${ }^{119}$ Thus, the requirements constituted a valid exercise of the police power.

4. Variations. In several cases, courts have applied tests that are essentially variations on the three tests discussed above. A few courts have adopted a test that is even more generous than the reasonable relationship test as applied in California. This judicial deference test, created by the Montana Supreme Court in Billings Properties, Inc. v. Yellowstone County, ${ }^{120}$ establishes a "virtually irrefutable presumption in favor of the exaction." ${ }^{21}$ It provides for the automatic acceptance of a legislative determination in favor of an exaction, unless the developer produces evidence demonstrating that the exaction is unreasonable. ${ }^{122}$ Thus, if the legislature had enacted a statute authorizing municipalities to exact dedications and fees from developers because of the increased demand on services and facilities resulting from new subdivisions, a reviewing court would accept the legislature's policy decision.

In Billings, the court considered a statute that declared itself to have been enacted pursuant to the state's police power, and that required the dedication

116. 338 So. 2d 863 (Fla. Dist. Ct. App. 1976), cert. denied, 348 So. 2d 955 (1977).

117. Id. at 868 .

118. Id. at 864 .

119. Id. at 868 .

120. 144 Mont. 25, 394 P.2d 182 (1964).

121. Gordon, supra note 104, at Al4, col. 4.

122. 144 Mont. at 35, 394 P.2d at 188. 
of land for parks and playgrounds. ${ }^{123}$ The court found that the subdivider voluntarily decided to subdivide the land and the statute was the state's response to that decision. As such, the imposition of reasonable conditions on the right to develop fell within the state's police power authority. ${ }^{124}$ Rather than determine for itself whether the subdivision created the need for the parks and playgrounds, the court deferred to the legislature. With a bit of circular reasoning, it found that the legislature had already answered the reasonableness question by enacting the law that required land dedications. ${ }^{125}$

The superficial review provided by this test resembles the standard applied under the earlier privilege test. ${ }^{126}$ Under both tests, the municipality enjoys broad discretion to regulate subdividers. The difference between the tests lies in the protections provided. The privilege test provided the subdivider no protection from the imposition of arbitrary and unreasonable conditions. The judicial deference test, however, permits the presentation of evidence to rebut the presumption of validity. ${ }^{127}$

This test has been applied in other situations as well. In Jenad, Inc. $v$. Village of Scarsdale, ${ }^{128}$ the New York Court of Appeals emphasized a similar police power rationale. At issue in that case was the imposition of an in-lieu fee requirement that would benefit the entire community. The statute at issue in Billings, on the other hand, imposed a requirement that would directly benefit the subdivision subject to the exaction. Thus, it appears that this test requires a showing only that the statute is substantially related to the state's police powers. It does not require that the legislation be reasonably related to the particular subdivision. ${ }^{129}$

A restrictive variation, more closely related to the specifically and uniquely attributable test, was set forth in Gulest Associates, Inc. v. Town of Newburgh. ${ }^{130}$ In that case, a New York court required a showing that the regulation would directly benefit the subdivision. The court held that the ordinance at issue, which required the payment of in-lieu fees, was unreasonable and constituted a taking. ${ }^{131}$ The ordinance provided that the funds collected were to be used for "neighborhood park, playground or recreation purposes including the acquisition of property." 132 The court found that this exaction was unreasonable because the funds collected could be used anywhere in the

123. Id. at 30,394 P.2d at $184-85$.

124. Id. at 32,394 P.2d at 186 .

125. Id. at 35,394 P. $2 \mathrm{~d}$ at 188 .

126. See supra notes 63-64 and accompanying text.

127. Pavelko, supra note 8 , at 283.

128. 18 N.Y.2d 78, 218 N.E.2d 673, 27 I N.Y.S.2d 955 (1966).

129. See Howard County v. JJM, Inc., 301 Md. 256, 276-77, 482 A.2d 908, 918 (1984), and sources cited therein.

130. 25 Misc. 2d 1004, 209 N.Y.S.2d 729 (Sup. Ct. 1960), affd, 15 A.D.2d 815, 225 N.Y.S.2d 538 (1962).

131. Id. at 1008,209 N.Y.S.2d at 733.

132. Id. at 1007,209 N.Y.S.2d at 732. 
town, and were not earmarked for expenditures directly benefiting the subdivision residents. ${ }^{133}$

This direct benefit test is based on the special assessment doctrine, a tax law principle. The special assessment doctrine provides that the costs of a service or improvement performed by the local government may be levied against real property if the benefits of the improvement will accrue directly to the assessed property. ${ }^{134}$ The restrictiveness of this test makes it difficult to maintain. As a result, the New York Court of Appeals has expressly overruled the decision in Gulest. ${ }^{135}$

\section{III \\ The NeEd to Unify the Existing Tests}

The tests discussed in Section II of this article were originally designed to assess the validity of traditional subdivision exactions. Different concerns arise when major user impact fees are at issue. Although the available tests are not suited to the assessment of the constitutionality of major user impact fees, courts continue to attempt to apply them..$^{136}$

The proliferation of divergent state tests and the absence of a federal test have given rise to several problems. For example, in choosing from among the three existing tests, courts must decide whether they prefer: (1) the vagueness of the reasonable relationship standard in which some benefit ultimately accruing to the subdivision is sufficient; (2) the excessive strictness of the specifically and uniquely attributable test and the ensuing difficulty the municipality faces in demonstrating the cause and effect relationship between the particular subdivision and the public improvement exacted; or (3) the fundamental neutrality of the rational nexus test. Furthermore, courts attempting to apply the tests often confuse the various standards. Occasionally, a court will enunciate one standard and actually apply another. ${ }^{137}$ More frequently, courts will refer to some of the tests interchangeably. ${ }^{38}$ In some cases, courts have begun to retreat from their polar positions. ${ }^{139}$

One problem inherent in some of these tests is that they consider only the needs leading to the imposition of the regulation, the benefits accruing from

133. Id.; 290 N.Y.S.2d at 732-33.

134. Juergensmeyer \& Blake, supra note 10 , at 429 ; Smith, supra note 31 , at 6 .

135. Jenad, Inc. v. Village of Scarsdale, 18 N.Y.2d 78, 218 N.E.2d 673, 27I N.Y.S.2d 955 (1966).

136. See, e.g., Contractors \& Builders Ass'n v. City of Dunedin, 329 So. 2d 314 (Fla. 1976), reconsidered on appeal from unpublished remand, 358 So. 2d 846 (Fla. Dist. Ct. App. 1978) (amended exaction held legal), cert. denied, 370 So. 2d 458, cert. denied, 444 U.S. 867 (1979); Banberry Dev. Corp. v. South Jordan City, 631 P.2d 899 (Utah 1981).

137. See, e.g. Jordan v. Village of Menomonee Falls, 28 Wis. 2d 608, 137 N.W.2d 442 (1965) (professing acceptance of specifically and uniquely attributable test but actually applying new rational nexus test), appeal dismissed, 385 U.S. 4 (1966).

138. See, e.g., Howard County v. JJM, Inc., 30I Md. 256, 280-81, 482 A.2d 908, 920 (1984) (mixing rational nexus and reasonable relationship tests).

139. See, e.g., Plote, Inc. v. Minnesota Alden Co., 96 Ill. App. 3d 1001, 1006-07, 422 N.E.2d 231, 235-36 (1981) (dictum showing that Illinois courts are tending toward a less restrictive test). 
the regulation, or neither. ${ }^{140}$ A balanced and equitable test must consider both of these elements. ${ }^{141}$ In addition, decisions regarding the validity of subdivision exactions and user impact fees should turn on the particular fact situation. Therefore, a court should adopt a flexible test that allows for varying treatment based on factual determinations. A court could therefore "accord more deferential treatment to the municipality's interests" when an exaction for on-site improvements is at issue and some need-benefit relationship to the new subdivision is assured. ${ }^{142}$ At the same time, when major off-site improvements are planned, the court could require a greater demonstration of the need for the regulation and a reasonable connection between the regulation and the new development. ${ }^{143}$

The consolidation of the existing tests into one unified, flexible test, applicable to subdivision exactions, user impact fees, and linkage, would simplify court review of these regulations and reduce the current confusion. An inquiry into the need created by the proposed development and the nexus between that need and the public benefits deriving from the imposition of the regulation is thus a preferable approach. To be equitable, such an inquiry must also balance the "legitimate interests of the developer and the general welfare concerns and power of the municipality." 144

\section{IV \\ The Proposed Needs-Nexus Test}

From the tests currently used to assess validity under the U.S. Constitution, it is possible to derive an equitable test that would consider the need-benefit relationships and balance the interests of local governments, developers, and consumers and yet remain understandable and simple to apply. In essence, the proposed new test, called the needs-nexus test, reaffirms the rational nexus test in slightly amended form as it pertains to subdivision exactions, while adapting it to fit the more complex issues and equities presented by user impact fees and linkage.

140. This problem is inherent in the specifically and uniquely attributable and direct benefit tests See supra text accompanying notes 81-99, 130-35.

141. Courts applying the rational nexus test have considered both needs and benefits. See, e.g. Hollywood, Inc. v. Broward County, 431 So. 2d 606, 611-12 (Fla. Dist. Ct. App. 1983); Jordan v. Village of Menomonee Falls, 28 Wis. 2d 608, 137 N.W.2d 442, appeal dismissed, 385 U.S. 4 (1966).

142. Pavelko, supra note 8 , at 291.

143. Id. at 292.

144. Juergensmeyer \& Blake, supra note 10, at 433. 
A chart setting forth the proposed new needs-nexus test is offered below:

\section{Needs-Nexus Test}

Subdivision Exactions

a) State enabling authority

b) Local enacting ordinance

c) Imposed at subdivision

a) Attributable to subdivision

a) Legitimate governmental police power objective; promotes public health, safety, welfare

b) Reasonable relation between public need served and exaction imposed

c) Burden of proof on subdivider

d) Amount of exaction is equitable
User Impact Fees/Linkage

Authority

a) State enabling authority

b) Local enacting ordinance

c) Imposed at development

Need

a) Area-wide or regional need

Nexus

a) Legitimate governmental police power objective; promotes public health, safety, welfare

b) Less intrusive alternatives not available

c) Burden of proof on government

d) Amount of fee or linkage is equitable

\section{A. Authority}

A court applying the needs-nexus test would first determine whether the municipality is authorized to impose the subdivision exaction, user impact fee, or linkage requirement. In order to find that a municipality has such authorization, state enabling legislation and a local enactment ordinance must exist. ${ }^{145}$ The same assessment would be made for subdivision exactions and user impact fees or linkage requirements. If authorization is found to exist, the court would then evaluate the constitutionality of the requirement by applying the next two steps of the test to ascertain the existence of the requisite need and nexus.

\section{B. Need and Nexus}

The need and nexus prongs of the test require inquiries into the source of the needs generated and the legitimacy and degree of governmental interest. Under this test, reviewing courts will scrutinize user impact fees and linkage more closely than traditional subdivision exactions. Therefore, a reviewing court must begin its application of the need and nexus prongs by determining whether the regulation at issue is a traditional subdivision exaction or a user impact fee. To make this determination, the definitions of subdivision exaction, user impact fee, and linkage provided in Section I of this article should be applied. ${ }^{146}$

145. See supra notes $46-55$ and accompanying text.

146. See supra pp. $139-40$. 
When a traditional subdivision exaction is at issue, the court will ask whether there is evidence that the need for the exaction was generated by the proposed subdivision. In order to find that an exaction dedication or construction of a facility is valid, there must exist a reasonable connection between the exaction and the needs created by or the benefits conferred upon the subdivision. Where only part of the need is generated by a particular proposal, the government may properly assess in-lieu fees equal to only that percentage. Thus, the subdivider will only pay for improvements resulting from the need created by the subdivision.

The reviewing court will also require evidence that the exaction rationally relates to a legitimate governmental objective. ${ }^{147}$ The burden of proof on this issue is placed on the subdivider to demonstrate that there is no legitimate governmental objective. A legitimate objective is one that promotes the public health, safety, or welfare. ${ }^{148}$ Recently, several courts reviewing subdivision exactions have expressly required that, to be considered valid exercises of a state's police power, exactions must be adopted to meet legitimate governmental objectives. ${ }^{149}$ For instance, in a case involving a park land dedication ordinance, the Texas Supreme Court held that a valid regulation 'must be 'substantially related' to the health, safety or general welfare of the people." 150

Where user impact fees are at issue, the reviewing court will conduct a similar need and nexus inquiry into the validity of the regulations. After determining whether a legitimate governmental objective exists, the court will ask whether there is evidence that the proposed development would contribute to a regional or area-wide need. Because it is possible to assess impact fees proportionately, the proposed development does not have to generate the entire need for the improvement. Instead, the development need only contribute to the condition requiring the public improvement. For example, the municipality may assess user impact fees to pay for a new school when the proposed development has contributed to the need for increased school capacity.

However, the burden of proof at this point would shift to the government to demonstrate that the need for user impact fees, as distinguished from subdivision exactions, cannot be satisfied by less intrusive alternatives, such as the real property tax. Additionally, the court will use a heightened standard of review in evaluating the government's case. This standard would entail close scrutiny, somewhat analogous to the strict scrutiny analysis employed by

147. The legitimate governmental objective requirement is derived from the rational basis standard of judicial review. For a discussion of this standard, see Tussman \& ten Broek, The Equal Protection of the Laws, 37 Calif. L. Rev. 341 (1949); see also G. Gunther, Constitutional Law 593-97 ( 1 lth ed. 1978); R. Rotunda, supra note 59, at $\$ \$ 15.4$, 18.3; L. Tribe, American Constitutional. LAw 994-96 (1978); Barrett, The Rational Basis Standard for Equal Protestion Review of Ordinary Legislative Classifications, $68 \mathrm{KY}$. L.J. 845, 856-66 (1980).

148. R. RotUNDA, supra note 59 , at $\$ \S 15.4,18.44$.

149. E.g., City of College Station v. Turtle Rock Corp., 680 S.W.2d 802 (Tex. 1984).

150. Id. at 805 . 
courts where fundamental rights or suspect classifications are involved in fourteenth amendment equal protection challenges. However, under the needs-nexus test, a compelling governmental interest in the user impact fee, linkage, or the underlying public improvement need not necessarily be shown. ${ }^{151}$ The reasons for shifting the burden and departing from the usual police power reasonableness standard with regard to user impact fees are as follows:

1. User impact fees represent a marked, if not radical, departure from the traditional method of financing major public improvements.

2. The costs associated with major off-site infrastructure improvements funded through user impact fees are typically considerably higher than those associated with traditional subdivision exactions. Thus, their effect upon the consumer is likely to be significant.

3. Subjecting residential developments to user impact fees raises important social, public policy, and constitutional issues, and potentially affects fundamental rights. These effects may offset the stated public interests normally cited in support of such fees. The primary issues raised by user impact fees are exclusion and housing discrimination based on economic status.

There is substantial potential for a community to abuse the user impact fee by making it a tool with which to exclude certain economic groups or classes. Economic discrimination is an ill that remains largely unaddressed by federal and state civil rights laws. ${ }^{152}$ With one notable exception, courts have also largely ignored the issue. The United States Supreme Court has not yet recognized the claim to affordable housing as a fundamental right protected by the Constitution. ${ }^{153}$ At the state level, only the New Jersey Supreme Court in its landmark "Mount Laurel" decisions ${ }^{154}$ has substantively addressed the question of economic discrimination in housing. In Mount Laurel I, the court was confronted with a region-wide problem of economic discrimination in housing, based on the technique of "fiscal zoning." Fiscal zoning is the use of the police power to enhance the tax base and provide good "ratables," while precluding or limiting high-density residential zoning in order to discourage

151. For a discussion of the strict scrutiny standard of judicial review, see G. Gunther, Constitutional Law, supra note 147 , at 588-89, 593; see also R. Rotunda, supra note 59 , at $\$ \S 15.4$, 18.3; L. TRIBE, supra note 147, at 602, 1002; Barrett, supra note 147, at 852-54. For additional discussion of the strict scrutiny standard, see infra notes 159-62.

152. See, e.g., The Fair Housing Act, 42 U.S.C. $\$ 3601-3631$ (1982). The Fair Housing Act makes it unlawful to make available or deny a dwelling to any person "because of race, color, religion, sex, or natural origin," but does not address discrimination in housing based upon economic status. Id. at $\$ 3604(\mathrm{a})$.

153. See Village of Belle Terre v. Boraas, 416 U.S. 1, 7 (1974).

154. See Southern Burlington County NAACP v. Township of Mt. Laurel, 67 N.J. 151, 336 A.2d 713, appeal dismissed, 423 U.S. 808 (1975) (Mt. Laurel I); Southern Burlington County NAACP v. Township of Mt. Laurel, 92 N.J. 158, 456 A.2d 390 (1983) (Mt. Iaurel II). In a third case, sometimes referred to as "Mt. Laurel III," the New Jersey Supreme Court upheld the State's Fair Housing Act of 1985 which transferred jurisdiction of pending Mount Laurel cases from the judiciary to a new agency created by the State Legislature. Hills Dev. Co. v. Bernards Township, 103 N.J. 1, 510 A.2d 621 (1986) (Mt. Laurel III). 
families with large numbers of school-aged children from moving to the municipality. The court found this practice to be economic discrimination in violation of the New Jersey Constitution. It therefore directed the affected municipalities to cease the practice and implement zoning policies that were designed to provide affordable housing opportunities based on each municipality's regional fair share of the need for such housing. ${ }^{155}$

The user impact fee can adversely affect regional opportunities for affordable housing to the same degree as the fiscal zoning practices condemned in the Mt. Laurel I and Mt. Laurel II decisions. This device is a politically tempting use of police power because most of those who will bear the burden of the fee are not yet residents, that is, voters, in the community. This forgotten constituency often consists of young families at the low end of the economic ladder seeking to purchase their first home. The user impact fee, like fiscal zoning, offers the municipal legislature an opportunity to address the difficult problems of financing needed public improvements without having to risk incurring the wrath of the electorate by increasing real estate assessments or the tax rate.

Thus, in reviewing a user impact fee ordinance, the court should examine whether there are less intrusive alternatives available, such as increasing the general tax rate or using general obligation bonds. In conducting this examination, the court should consider some or all of the following questions:

- What is the amount of the fee and its likely impact upon the ultimate consumer when passed through by the developer? For example, in the case of a dwelling, it has been estimated that over the life of a 30-year mortgage, a $\$ 2,376.00$ impact fee results in a total cost to the home purchaser of $\$ 13,878.00 .156$

- How healthy is the municipality's assessable base? Is it growing or eroding?

- Is the municipality's tax rate low in comparison to similarly situated political subdivisions?

- What is the municipality's bond rating? Will increased taxes or borrowing to fund public improvements jeopardize it?

- Has the municipality's current capital improvements program (CIP) kept pace with previous programs? How does the current CIP compare to its predecessors in relation to the current size of the municipality and growth trends?

- Is the municipality's existing housing stock sufficiently diverse and inclusionary to accommodate a variety of income groups including lowand moderate-income families?

155. 92 N.J. at 198-99, 456 A.2d at 410 . The failure of Mount Laurel and other communities to implement the court's directives in $M$. Latrel I gave rise to this $M$. Laurel II litigation several years later.

156. NAHB Developer's Manual, supra note 37, at 3-4. If the fee is imposed on nonresidential development, the inquiry would focus on its effect on employment opportunities, sales tax collections, increased disposable income, and economic development of the community. 
- Is the fee, in reality, a double tax on the consumer? In other words, is the new-home purchaser, who, like existing residents, pays deductible property taxes for services, and also must pay a nondeductible impact fee for the same service (through the increased price of the home), essentially paying twice? ${ }^{157}$

The reviewing court should also consider several of the factors raised by the Utah Supreme Court in Banberry Dev. Corp. v. South Jordan City: 158

- What are the costs of existing capital facilities and how have they been financed?

- Has the property charged with the fee already contributed to the costs of existing facilities? To what extent will it contribute to the cost of existing facilities in the future?

- Is the affected property being credited for providing common facilities that the municipality has provided without charge to other properties in the service area?

- What extraordinary costs, if any, will be incurred in serving the affected property?

- Has a time-price differential been included in making comparisons of amounts paid by the affected property and other properties at different times?

The answers to these questions do not all have to favor the government's position in order for the government to demonstrate that less intrusive alternatives to the user impact fee are unavailable. If, on balance, however, the answers to many of these questions are adverse to the imposition of the fee, the court should hold that the government has not sustained its burden.

To recapitulate, under the nexus portion of the test, the burden of proof would shift to the municipality to demonstrate that less intrusive means of financing the needed public improvements are unavailable. In reviewing the requirement, the court would use a close scrutiny standard rather than the minimal scrutiny criterion applicable to equal protection claims, or the reasonableness standard normally applied in weighing due process challenges to police power actions.

The needs and nexus prongs of the test also address the equity of the regulation. Once again, the assessment is more stringent for user impact fees or linkage requirements than for subdivision exactions because of the former's potentially greater impact upon the consumer. For an exaction to withstand scrutiny under the equity analysis, the government must show that a reasonable relationship exists between the public need served by it and the type and extent of the exaction. The municipality may not impose the exaction arbitrarily, ${ }^{159}$ and the amount of the exaction must be equitable,

157. See id. at 4 .

158. 631 P.2d 899, 903-05 (Utah 1981); see also Lafferty v. Payson City, 642 P.2d 376 (Utah 1982).

159. A requirement that bears no relationship to the promotion of public health and safety is arbitrary and capricious. E.g., Coates v. Planning Bd., 58 N.Y.2d 800, 802, 445 N.E.2d 642, 643, 459 N.Y.S.2d 259, 260 (1983). 
given the need directly created by the proposed subdivision. In making such an assessment, the Texas Supreme Court recently inquired into the reasonableness of the connection between the development of a subdivision and the increased park and recreation needs in the neighborhood for which exactions were sought. ${ }^{160}$ Additionally, the municipality may not impose the entire cost of an improvement on a development through exaction dedication or in-lieu fee requirements where the development generates only a portion of the need for the improvement. Only those costs fairly attributable to the subdivision may be imposed through exactions. ${ }^{161}$

As applied to user impact fees and linkage, equity requires that there be no less intrusive alternatives available to achieve the stated governmental objective. ${ }^{162}$ Examples of less intrusive alternatives could, in certain circumstances, include special assessment taxes, general revenue bond issues or federal or state grants. The government should bear the burden of demonstrating the absence of less intrusive alternatives.

Furthermore, as was the case for subdivision exactions, the amount of the burden imposed through user impact fees and linkage may not exceed the fair share of the need imposed by the development itself. For instance, a Florida court has upheld an ordinance that employed a formula to determine a development's fair share of the costs of road construction. ${ }^{163}$ The ordinance set different fees for single-family houses, multifamily houses, mobile homes, and commercial units, since the different types of land uses generate varying numbers of motor vehicle trips. ${ }^{164}$

In summary, the new needs-nexus test for subdivision exactions, user impact fees, and linkage requires first that the municipality be authorized to impose the regulation. The reviewing court must then consider the new development or subdivision's relationship to the need for the improvement, the government's interest in enacting the regulation, the equity of the regulation as determined by its necessity, and the fairness of the amount imposed. A reviewing court applying the needs-nexus test will uphold a regulation if all of these elements are found to exist.

\section{$\mathrm{V}$}

\section{Legal Rationale for the NeEds-Nexus Test}

As described above, ${ }^{165}$ the proposed needs-nexus test draws a distinction between traditional subdivision exactions and the newer user impact fees and linkage. This distinction is based on the different degrees and types of need created by proposed developments and the nexus between the need created

160. City of College Station v. Turtle Rock Corp., 680 S.W.2d 802 (Tex. 1984).

161. See supra text accompanying note 115 .

162. R. RotUNDA, supra note 59 , at $\$ 18.3$.

163. Home Builders \& Contractors Ass'n v. Board of County Comm'rs, 446 So. 2d 140 (Fla. Dist. Ct. App. 1983), appeal dismissed, 469 U.S. 976-77 (1984).

164. Id. at 142 .

165. See supra section IV. 
and the public benefit to be served by imposing the regulation. At the same time, courts applying the test will consider similar elements (that is, authority, need, nexus, and equity) regardless of whether subdivision exactions or user impact fees or linkage are in dispute.

The new needs-nexus test refines and consolidates the existing proliferation of tests that courts presently use to determine whether particular subdivision exactions and user impact fees or linkage have been authorized and constitutionally imposed. The result is a flexible, unified test that can be applied to both traditional on-site subdivision exactions and modern off-site user impact fees and linkage.

In addition, the new test ensures that municipalities' use of these regulations will not infringe upon constitutionally protected property rights. Regulations may not be imposed if they violate the equal protection or due process provisions of the Constitution, if they would constitute a taking without compensation, or if they exceed the municipality's police power authority. The legitimate governmental objective, reasonable relationship, and no less intrusive alternative components of the test are derived from standards generally used in equal protection and due process review.

As stated in the preceding section, equal protection and exclusionary concerns necessitate the requirement that the local government assume the burden of demonstrating the absence of less intrusive alternatives when user impact fees or linkage are at issue. User impact fees and linkage require large expenditures by developers that, in whole or in part, are passed through to the consumer, resulting in higher housing prices or commercial rental rates. ${ }^{166}$ To impose these costs on the developer and the new users of the development, rather than on the general populace, is inequitable unless no alternative financing exists. The increased prices also potentially exclude many prospective residents from high growth areas by making already scarce low- and moderate-income housing even more difficult to find.167 In particular, first-time home buyers with limited financial resources will have an increasingly difficult time finding affordable new housing. ${ }^{168}$

166. D. MANDELKer, supra note 9, at 271-72; Uli Statement, supra note 37, at 19

In addition, according to the National Association of Home Builders:

The imposition of impact fees on new development can also produce a ripple effect throughout an entire housing market, affecting both new home sales and existing home resales. When impact fees and other cost factors contribute to escalating new home selling prices, prospective home buyers may be restricted to the resale market, resulting in a windfall for owners of older units.

NAHB Developer's ManUal, supra note 37, at 5.

One commentator, however, sees the imposition of fees as an attempt by the municipality to recapture part of the increase in land values it has "given" to landowners over the years. Hagman, Exactions, User Fees and Assessments: What Are the Limits?, in 1983 Zoning and Planning Law Handbook 45.

167. See Heyman \& Gilhool, supra note 15, at 1134 ; see also NAHB Developer's Manual, supra note 37, at 1, 5; Weitz, Impact Fees: There Is No Free Lunch, PLAN., July 1984, at 12.

168. See NAHB Developer's Manual, supra note 37 , at 1,5 . In 1980 , an appellate court in Oregon found that every $\$ 1,000$ increase in housing costs excluded an additional nine percent of the market. State Hous. Council v. City of Lake Oswego, 48 Or. App. 525, 532, 617 P.2d 655, 659 (1980), appeal dismissed, 291 Or. 878, 635 P.2d 647 (1981). 
In addition, it is inequitable to force the costs of these major improvements on new purchasers and renters alone. The funds or land and facilities acquired through these regulations have been traditionally supplied by local governments. Historically, all local residents have helped to bear these costs since governments obtained the funds through taxing and other revenue raising powers. Local governments are still responsible for the provision of services and facilities that benefit the whole community. ${ }^{169}$ Thus, to impose an additional charge solely upon the new homeowner or tenant raises basic questions of social equity. As expressed by the New Jersey Supreme Court:

But as to services which traditionally have been supported by general taxation, other considerations are evident. The dollar burden would likely be unequal if new homes were subjected to a charge in addition to the general tax rate. As to education, for example, the vacant land has contributed for years to the cost of existing educational facilities, and that land and the dwellings to be erected will continue to contribute with all other real property to the payment of bonds issued for the existing facilities and to the cost of renovating or replacing those facilities. Hence, there would be an imbalance if new construction alone were to bear the capital cost of new schools while being also charged with the capital costs of schools serving other portions of the school district. ${ }^{70}$

The same analysis applies to the imposition of charges for other major public facilities such as highways, central water and sewage treatment facilities, and landfills.

\section{VI \\ ConClusion}

Thirty years ago, Justice Frankfurter foretold that

[y] esterday the active area in this field [of law] was concerned with 'property.' Today it is 'civil liberties.' Tomorrow it may again be 'property.' Who can say that in a society with a mixed economy, like ours, these two areas are sharply separated, and that certain freedoms in relation to property may not again be deemed, as they were in the past, aspects of individual freedom. ${ }^{171}$

Subdivision exaction and its more recent offshoots, user impact fees and linkage, add credence to Justice Frankfurter's clairvoyance.

The earliest subdivision exactions, requirements that subdividers dedicate land to the local government for street and utility easement purposes, were closely tied to the subject subdivision. The needs creating the requirement were generated by the new residential subdivision and the benefits derived from the improvements would accrue to that particular property because the improvements would be placed on-site. Over the last two decades, because of increased demands and financial constraints experienced by local governments, other forms of regulations have appeared. These measures

169. Pavelko, supra note 8, at 270-71.

170. West Park Ave., Inc. v. Ocean Township, 48 N.J. 122, 126-27, 224 A.2d 1, 3-4 (1966); see also Contractors \& Builders Ass'n v. City of Dunedin, 329 So. 2d 314 (Fla. 1976), reconsidered on appeal from unpublished remand, 358 So. 2d 846 (Fla. Dist. Ct. App. 1978) (amended exaction held legal), cert. denied, 370 So. 2d 458, cert. denied, 444 U.S. 867 (1979).

171. F. Frankfurter, Of Law and Men 19 (1956). 
include such additional subdivision exactions as minor off-site dedication requirements, in-lieu fees and, more recently, major off-site user impact fees and linkage. The imposition of these latter devices is not as closely tied to the needs generated by the new developments or to the benefits that accrue to the new residents.

Several judicial tests have been used to evaluate the validity of subdivision exactions and user impact fees. The first inquiry asks whether the municipality is authorized to impose the exaction or impact fee. If the answer to this question is affirmative, the regulation's constitutionality is examined. State courts have applied the reasonable relationship, specifically and uniquely attributable, and rational nexus tests as well as combinations or offshoots of these three major tests.

Because of problems with these tests and because of the expanding nature of the regulations imposed, this article proposes a new test for subdivision exaction, user impact fee, and linkage validity. Under the new test, the reviewing court would first determine whether the municipality has the authority to impose the regulation. It would then determine whether the regulation is a traditional subdivision exaction or one of the newer user impact fees or linkage. If the regulation is an exaction, the court would ask whether the need for it is generated by the proposed subdivision, whether there is a reasonable relationship between the public need served and the exaction imposed, and whether it serves a legitimate governmental objective. If a user impact fee or linkage is involved, the court would ask whether there is a regional or area-wide need to which the proposed development would contribute, whether this need represents a legitimate governmental objective, and whether a less intrusive alternative is available. The burden of responding to the less intrusive alternative inquiry would shift to the government, and the court would employ a close scrutiny standard. For both types of regulation, the court would require that the municipality impose only a fair share contribution on the developer.

The proposed test would thus incorporate standards that are well established in constitutional law. Courts applying the needs-nexus test would be able to consider the effects of the regulations on equal protection. They would also be able to consider exclusionary concerns. In addition, they would be able to require a somewhat greater nexus between the impact fee or linkage and the development where major off-site infrastructure requirements are involved. In this way, courts applying the proposed test to subdivision exactions and user impact fees or linkage would be better able to consider the need-benefit relationships, balance the interests of local governments, developers and consumers, and achieve equitable results. 